\title{
Analysis of High-Power LED Packages with Diamond and CNT Film
}

\author{
Cheng Yi Hsu and Yuli Lin
}

\begin{abstract}
In this study, analysis using high thermal conductive material for measuring junction temperature $(\mathrm{Tj})$ in high power GaN-based light emitting diodes (LED) was presented. Thermal characteristics of high power Light-emitting-diode have been analyzed by using various different structure conduction models. The forward operation voltage is advantageously used to measure the junction temperature of light emitting diodes. Using this method, junction temperature (Tj) of LED under various structures and chip mounting methods was measured. It was found that the junction temperature can be reduced considerably by using diamond film substrates and CNT film substrates. In this study, for model $F$ structure, the junction temperature using diamond film can be decreased by about $10.8 \%$ under $1.5 \mathrm{~W}$ power, decreased by about $12 \%$ under $2.6 \mathrm{~W}$ power and decreased by about $11.6 \%$ under $4.2 \mathrm{~W}$ power for $1 \mathrm{~mm}$ square die. The junction temperature using CNT film can be decreased by about $12.7 \%$ under $1.5 \mathrm{~W}$ power, decreased by about $14.1 \%$ under $2.6 \mathrm{~W}$ power and decreased by about $14.2 \%$ under $4.2 \mathrm{~W}$ power for $1 \mathrm{~mm}$ square die. The thermal resistance (RT) of diamond film can be measured to be $12.6^{\circ} \mathrm{C} / \mathrm{W}$ under $4.2 \mathrm{~W}$ power and the thermal resistance (RT) of CNT film can be measured to be $12.2^{\circ} \mathrm{C} / \mathrm{W}$ under $4.2 \mathrm{~W}$.
\end{abstract}

Index Terms-Junction temperature, diamond film, light-emitting-diode, CNT film.

\section{INTRODUCTION}

For green energy, the Light Emitting Diode (LED) can be optimally used for general lighting. However, high temperature problem have to be resolved when it is to be used in long time and higher power lighting. Accordingly, the lighting applications of LED technologies have been developed to have lower junction temperature and lower thermal resistance (RT). However, the input electrical energy into the LED device which becomes photons and are immediately emitted out of the device, while the rest photons remains inside the LED device which produced heat, that increases the junction temperature. Sapphire substrate is used in the tradition LED. This material has poor heat dissipation characteristic. And poor reliability in LED structure always exists depends on the thermal temperature and package structure [1]-[12]. Therefore, the problem of heat dissipation in LED is certain to happen in high-power applications. In this paper, we will report the result of High-Power LED packages with diamond and CNT film in various heat

Manuscript received August 23, 2016; revised December 20, 2016. This work was supported in part by Ministry of Science and Technology under Grant NSC 98-2221-E216-008.

Cheng Yi Hsu and Yuli Lin are with College of Engineering, Chung Hua University, Hsinchu, Taiwan (e-mail: d09724003@chu.edu.tw, yulilin@chu.edu.tw). dissipation structures.

TABLE I: PHYSICAL PARAMETERS OF VARIOUS DISSIPATION MODES USED

\begin{tabular}{|c|c|c|c|c|c|c|}
\hline \multicolumn{7}{|c|}{ IN THIS STUDY } \\
\hline Structure & $\begin{array}{c}\text { Model } \\
\text { A }\end{array}$ & $\begin{array}{l}\text { Model } \\
\text { B }\end{array}$ & $\begin{array}{l}\text { Model } \\
\text { C }\end{array}$ & $\begin{array}{l}\text { Model } \\
\text { D }\end{array}$ & $\begin{array}{l}\text { Model } \\
\text { E }\end{array}$ & $\begin{array}{c}\text { Model } \\
\mathrm{F}\end{array}$ \\
\hline & \multicolumn{6}{|c|}{$\mathrm{GaN}\left(1 \mathrm{~mm} * 1 \mathrm{~mm}^{*} 5 \mu \mathrm{m}\right)$} \\
\hline$(\mathrm{L} * \mathrm{~W} * \mathrm{H})$ & \multicolumn{6}{|c|}{ Sapphire $\left(1 \mathrm{~mm}^{*} 1 \mathrm{~mm}^{*} 90 \mu \mathrm{m}\right)$} \\
\hline $\begin{array}{l}\text { Adhesion } \\
\text { Material }\end{array}$ & \multicolumn{6}{|c|}{ Silver epoxy $5 \mu \mathrm{m}$} \\
\hline $\begin{array}{l}\text { High thermal } \\
\text { conductivity } \\
\text { Material } \\
\text { (Heat Sink) } \\
\text { Dimensions L } \\
* \text { W * H }\end{array}$ & \multicolumn{6}{|c|}{$\begin{array}{l}\text { 1. No Heat Sink } \\
\text { 2. Diamond Film }\left(1 \mathrm{~mm}^{*} 1 \mathrm{~mm}^{*} 20 \mu \mathrm{m}\right) \\
\text { 3. CNT Film }\left(1 \mathrm{~mm}^{*} 1 \mathrm{~mm}^{*} 1 \mu \mathrm{m}\right)\end{array}$} \\
\hline $\begin{array}{l}\text { Adhesion } \\
\text { Material }\end{array}$ & \multicolumn{6}{|c|}{ Silver epoxy $5 \mu \mathrm{m}$} \\
\hline $\begin{array}{l}\text { Board } \\
\text { Material }\left(L^{*}\right. \\
\mathrm{W} * \mathrm{H})\end{array}$ & $\begin{array}{c}\text { Al plate } \\
\left(80 \mathrm{~mm}^{*}\right. \\
40 \mathrm{~mm} \\
* 0.1 \mathrm{~mm})\end{array}$ & $\begin{array}{c}\text { Al plate ( } \\
80 \mathrm{~mm} * \\
40 \mathrm{~mm} \\
* 0.2 \mathrm{~mm})\end{array}$ & $\begin{array}{c}\text { Al plate } \\
(80 \mathrm{~mm} * \\
40 \mathrm{~mm} \\
* 0.4 \mathrm{~mm})\end{array}$ & $\begin{array}{l}\mathrm{Cu} / \mathrm{Al} \text { plate } \\
(80 \mathrm{~mm} \\
* 40 \mathrm{~mm} \\
* 0.1 / 0.3 \mathrm{~mm})\end{array}$ & $\begin{array}{l}\mathrm{Cu} / \mathrm{Al} \text { plate } \\
(80 \mathrm{~mm} \\
* 40 \mathrm{~mm} \\
* 0.2 / 0.2 \mathrm{~mm})\end{array}$ & $\begin{array}{l}\text { Cu plate } \\
(100 \mathrm{~mm} \\
* 80 \mathrm{~mm} \\
* 3 \mathrm{~mm})\end{array}$ \\
\hline
\end{tabular}

\section{EXPERIMENT PROCEDURE}

The samples utilized in this work are diamond film and CNT film, which were put on three different substrates. The thickness of the diamond film is $20 \mu \mathrm{m}$ and the thickness of the CNT film is $1 \mu \mathrm{m}$. In this work, we established four kinds of heat dissipation models. Table I shows the physical parameters of the models. In our models, normal GaN /Sapphire blue high power LED was utilized. And the samples are 40 mil blue GaN LED chips obtained from an LED manufacturer. Fig. 1(a) schematically shows the first heat dissipation model which is symbolized as model A. In this model of Al plate with $0.1 \mathrm{~mm}$ of thickness have three different structures, first, the high power LED GaN Epitaxy with sapphire substrate was not mounted onto the heat sink structure which is symbolized as model A-1. Second, the high power LED GaN Epitaxy with sapphire substrate was mounted onto a high thermal conductive material of diamond film using silver epoxy which is symbolized as model A-2. Third, the high power LED GaN Epitaxy with sapphire substrate was mounted onto a high thermal conductive material of CNT film using silver epoxy which is symbolized as model A-3. The thicknesses of the nitride film and sapphire substrate are $5 \mu \mathrm{m}$ and $90 \mu \mathrm{m}$, Fig. 1(b) shows the second heat dissipation model which is symbolized as model B. In this model of Al plate with $0.2 \mathrm{~mm}$ of thickness has three different structures which were no heat sink and diamond film and CNT film which is symbolized as model B-1, B-2 and B-3. Fig. 1(c) shows the third heat dissipation model which is symbolized as model $\mathrm{C}$. In this model of $\mathrm{Al}$ 
plate with $0.4 \mathrm{~mm}$ of thickness has three different structures which were no heat sink and diamond film and CNT film which is symbolized as model C-1, C-2 and C-3. Fig. 1(d) shows the fourth heat dissipation model which is symbolized as model $\mathrm{D}$. In this model of $\mathrm{Cu} / \mathrm{Al}$ plate with $0.1 / 0.3 \mathrm{~mm}$ of thickness has three different structures which were no heat sink and diamond film and CNT film which is symbolized as model D-1, D-2 and D-3. Fig. 1(e) shows the fifth heat dissipation model which is symbolized as model E. In this model of $\mathrm{Cu} / \mathrm{Al}$ plate with $0.2 / 0.2 \mathrm{~mm}$ of thickness has three different structures which were no heat sink and diamond film and CNT film which is symbolized as model E-1, E-2 and E-3. Fig. 1(f) shows the sixth heat dissipation model which is symbolized as model $\mathrm{F}$. In this model of $\mathrm{Cu}$ plate with $3 \mathrm{~mm}$ of thickness has three different structures which were no heat sink and diamond film and CNT film which is symbolized as model F-1, F-2 and F-3.
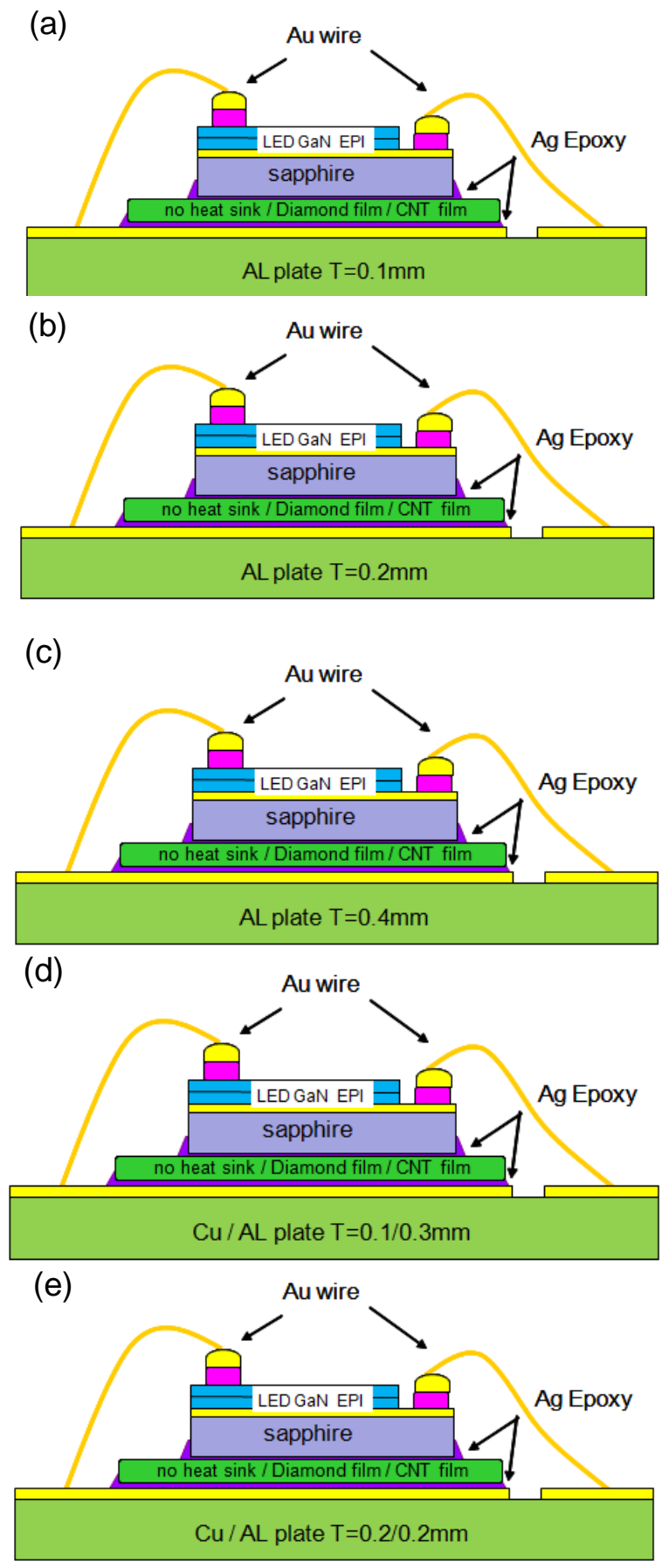

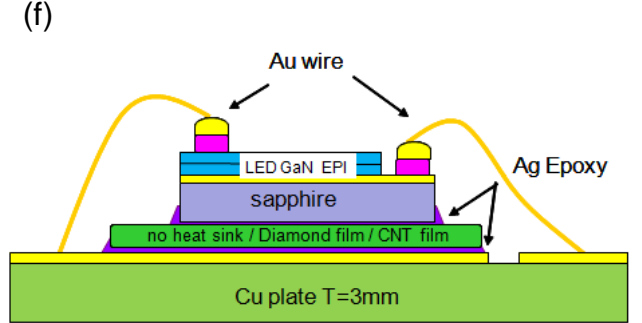

Fig. 1. Configurations of six heat dissipation structures: LED with 3 different type films on (a) Al plate with $0.1 \mathrm{~mm}$ of thickness and (b) Al plate with 0.2 $\mathrm{mm}$ of thickness and (c) Al plate with $0.4 \mathrm{~mm}$ of thickness and (d) $\mathrm{Cu} / \mathrm{Al}$ plate with $0.1 / 0.3 \mathrm{~mm}$ of thickness and (e) $\mathrm{Cu} / \mathrm{Al}$ plate with $0.2 / 0.2 \mathrm{~mm}$ of thickness and (f) $\mathrm{Cu}$ plate with $3 \mathrm{~mm}$ of thickness.

\section{RESUlTS AND DISCUSSIONS}

From the experiments result, for model A structure, Fig. 2 shows the junction temperature of diamond film can be decreased by about $9.6 \%$ under $4.2 \mathrm{~W}$ power and the junction temperature of CNT film can be decreased by about $11.8 \%$ under $4.2 \mathrm{~W}$ power for $1 \mathrm{~mm}$ square die. Fig. 3 shows the thermal resistance of junction to air on model A structure, the thermal resistance (RT) of diamond film can be measured to be $13.6^{\circ} \mathrm{C} / \mathrm{W}$ under $4.2 \mathrm{~W}$ power and the thermal resistance (RT) of CNT film can be measured to be $13.2^{\circ} \mathrm{C} / \mathrm{W}$ under $4.2 \mathrm{~W}$ power which is the lower than A-1 and A-2 structures. Table II demonstrates the experimental results for junction temperature and thermal resistance measurements on model A structure.

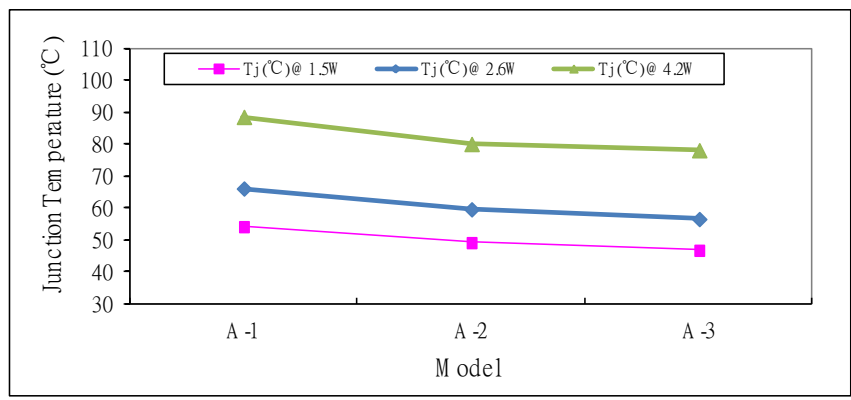

Fig. 2. Junction temperature measurement under $1.5 \mathrm{~W}, 2.6 \mathrm{~W}$ and $4.2 \mathrm{~W}$ conditions on model A structure.

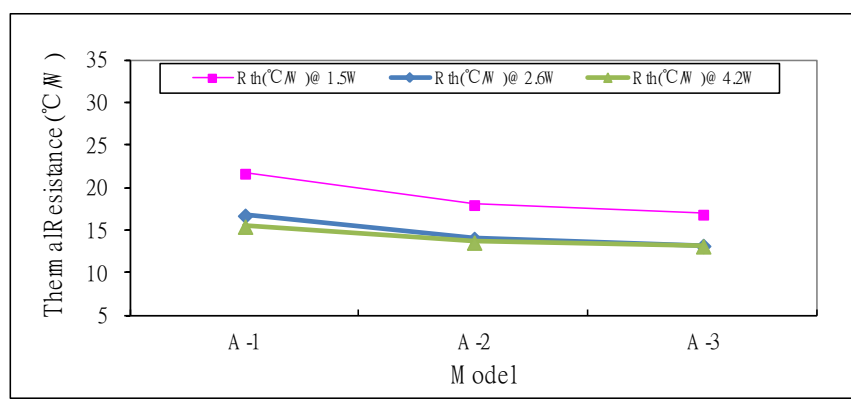

Fig. 3. Thermal resistance measurement under $1.5 \mathrm{~W}, 2.6 \mathrm{~W}$ and $4.2 \mathrm{~W}$ conditions on model A structure.

TABLE II: EXPERIMENTAL RESULTS OF JUNCTION TEMPERATURE AND THERMAL RESISTANCE ON MODEL A STRUCTURE

\begin{tabular}{|l|l|c|c|c|c|c|c|}
\hline Model & Structure & $\begin{array}{c}\text { Rth } \\
\left({ }^{\circ} \mathrm{C} / \mathrm{W}\right) \\
@ 1.5 \mathrm{~W}\end{array}$ & $\begin{array}{c}\mathrm{Tj} \\
\left({ }^{\circ} \mathrm{C}\right) \\
@ 1.5 \mathrm{~W}\end{array}$ & $\begin{array}{c}\text { Rth } \\
\left({ }^{\circ} \mathrm{C} / \mathrm{W}\right) \\
@ 2.6 \mathrm{~W}\end{array}$ & $\begin{array}{c}\mathrm{Tj} \\
\left({ }^{\circ} \mathrm{C}\right)\end{array}$ & $\begin{array}{c}\mathrm{R} \text { th } \\
\left({ }^{\circ} \mathrm{C} / \mathrm{W}\right)\end{array}$ & $\begin{array}{c}\mathrm{Tj} \\
\left({ }^{\circ} \mathrm{C}\right)\end{array}$ \\
\hline A-1 & LED Structure (no heat sink $)$ & 21.75 & 54.30 & 16.80 & 66.24 & 15.52 & 88.66 \\
\hline A-2 & LED on Diamond Film & 18.06 & 49.30 & 14.07 & 59.72 & 13.64 & 80.19 \\
\hline A-3 & LED on CNT Film & 16.93 & 46.90 & 13.25 & 56.68 & 13.20 & 78.23 \\
\hline
\end{tabular}

From the experiments result, for model B structure, Fig. 4 shows the junction temperature of diamond film can be 
decreased by about $9.6 \%$ under $4.2 \mathrm{~W}$ power and the junction temperature of CNT film can be decreased by about $13.5 \%$ under $4.2 \mathrm{~W}$ power for $1 \mathrm{~mm}$ square die. Fig. 5 shows the thermal resistance of junction to air on model B structure, the thermal resistance (RT) of diamond film can be measured to be $13.8^{\circ} \mathrm{C} / \mathrm{W}$ under $4.2 \mathrm{~W}$ power and the thermal resistance (RT) of CNT film can be measured to be $13.0^{\circ} \mathrm{C} / \mathrm{W}$ under $4.2 \mathrm{~W}$ power which is the lower than B-1 and B-2 structures. Table III demonstrates the experimental results for junction temperature and thermal resistance measurements on model B structure.

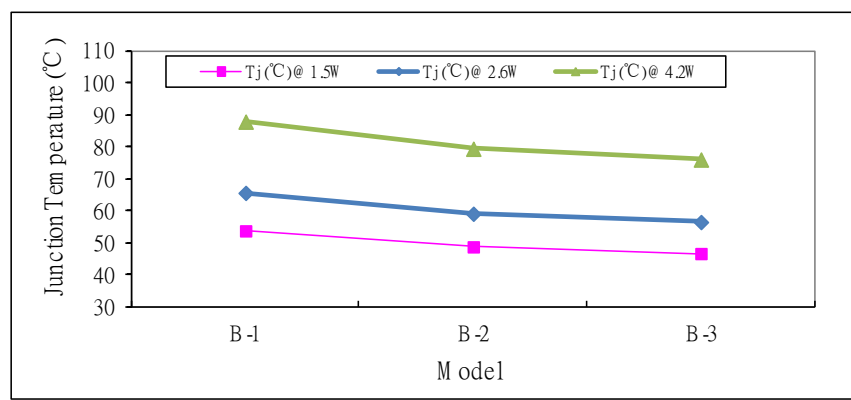

Fig. 4. Junction temperature measurement under $1.5 \mathrm{~W}, 2.6 \mathrm{~W}$ and $4.2 \mathrm{~W}$ conditions on model B structure.

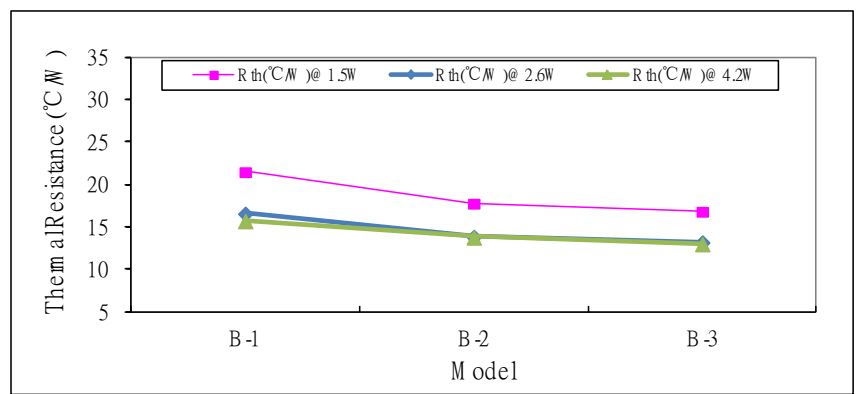

Fig. 5. Thermal resistance measurement under 1.5W, 2.6W and 4.2W conditions on model B structure.

TABLE III: EXPERIMENTAL RESULTS OF JUNCTION TEMPERATURE AND THERMAL RESISTANCE ON MODEL B STRUCTURE

\begin{tabular}{|l|l|c|c|c|c|c|c|}
\hline Model & Structure & $\begin{array}{c}\text { Rth } \\
\left({ }^{\circ} \mathrm{C} / \mathrm{W}\right) \\
@ 1.5 \mathrm{~W}\end{array}$ & $\begin{array}{c}\mathrm{Tj} \\
\left({ }^{\circ} \mathrm{C}\right)\end{array}$ & $\begin{array}{c}\text { Rth } \\
\left({ }^{\circ} \mathrm{C} / \mathrm{W}\right)\end{array}$ & $\begin{array}{c}\mathrm{Tj} \\
\left({ }^{\circ} \mathrm{C}\right) \\
@ 22.6 \mathrm{~W}\end{array}$ & $\begin{array}{c}\mathrm{R} \text { th } \\
\left({ }^{\circ} \mathrm{C} / \mathrm{W}\right)\end{array}$ & $\begin{array}{c}\mathrm{Tj} \\
\left({ }^{\circ} \mathrm{C}\right)\end{array}$ \\
\hline B-1 & LED Structure (no heat sink) & 21.55 & 53.90 & 16.64 & 65.76 & 15.77 & 88.04 \\
\hline B-2 & LED on Diamond Film & 17.83 & 48.90 & 13.91 & 59.24 & 13.84 & 79.56 \\
\hline B-3 & LED on CNT Film & 16.88 & 46.80 & 13.25 & 56.65 & 13.06 & 76.20 \\
\hline
\end{tabular}

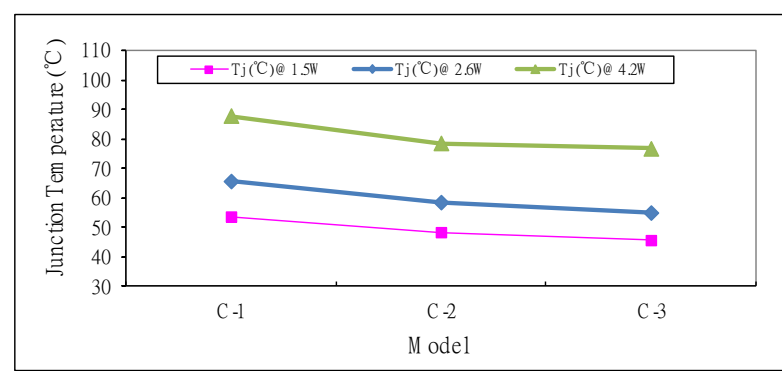

Fig. 6. Junction temperature measurement under $1.5 \mathrm{~W}, 2.6 \mathrm{~W}$ and $4.2 \mathrm{~W}$ conditions on model $\mathrm{C}$ structure.

From the experiments result, for model $\mathrm{C}$ structure, Fig. 6 shows the junction temperature of diamond film can be decreased by about $10.6 \%$ under $4.2 \mathrm{~W}$ power and the junction temperature of CNT film can be decreased by about $12.7 \%$ under $4.2 \mathrm{~W}$ power for $1 \mathrm{~mm}$ square die. Fig. 7 shows the thermal resistance of junction to air on model B structure, the thermal resistance (RT) of diamond film can be measured to be $13.2^{\circ} \mathrm{C} / \mathrm{W}$ under $4.2 \mathrm{~W}$ power and the thermal resistance
(RT) of CNT film can be measured to be $12.8^{\circ} \mathrm{C} / \mathrm{W}$ under $4.2 \mathrm{~W}$ power which is the lower than $\mathrm{C}-1$ and $\mathrm{C}-2$ structures. Table IV demonstrates the experimental results for junction temperature and thermal resistance measurements on model C structure.

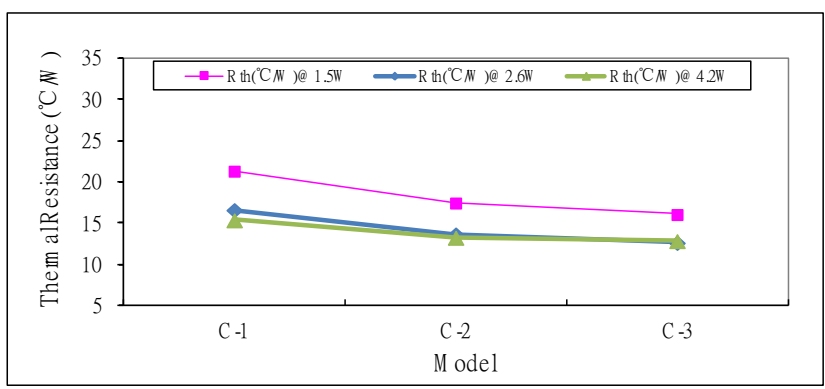

Fig. 7. Thermal resistance measurement under $1.5 \mathrm{~W}, 2.6 \mathrm{~W}$ and $4.2 \mathrm{~W}$ conditions on model $\mathrm{C}$ structure.

TABLE IV: EXPERIMENTAL RESULTS OF JUNCTION TEMPERATURE AND THERMAL RESISTANCE ON MODEL C STRUCTURE

\begin{tabular}{|l|l|c|c|c|c|c|c|}
\hline Model & Structure & $\begin{array}{c}\text { Rth } \\
\left({ }^{\circ} \mathrm{C} / \mathrm{W}\right) \\
@ 1.5 \mathrm{~W}\end{array}$ & $\begin{array}{c}\mathrm{Tj} \\
\left({ }^{\circ} \mathrm{C}\right)\end{array}$ & $\begin{array}{c}\text { Rth } \\
\left({ }^{\circ} \mathrm{C} / \mathrm{W}\right)\end{array}$ & $\begin{array}{c}\mathrm{Tj} \\
\left({ }^{\circ} \mathrm{C}\right) \\
@ 2 \mathrm{~W}\end{array}$ & $\begin{array}{c}\text { Rth } \\
\left({ }^{\circ} \mathrm{C} / \mathrm{W}\right)\end{array}$ & $\begin{array}{c}\mathrm{Tj} \\
\left({ }^{\circ} \mathrm{C}\right)\end{array}$ \\
\hline $\mathrm{C}-1$ & LED Structure (no heat sink) & 21.34 & 53.60 & 16.61 & 65.65 & 15.37 & 87.90 \\
\hline $\mathrm{C}-2$ & LED on Diamond Film & 17.47 & 48.30 & 13.65 & 58.49 & 13.25 & 78.59 \\
\hline $\mathrm{C}-3$ & LED on CNT Film & 16.07 & 45.60 & 12.62 & 54.95 & 12.84 & 76.75 \\
\hline
\end{tabular}

From the experiments result, for model D structure, Fig. 8 shows the junction temperature of diamond film can be decreased by about $11.3 \%$ under $4.2 \mathrm{~W}$ power and the junction temperature of CNT film can be decreased by about $15.3 \%$ under $4.2 \mathrm{~W}$ power for $1 \mathrm{~mm}$ square die. Fig. 9 shows the thermal resistance of junction to air on model B structure, the thermal resistance (RT) of diamond film can be measured to be $13.3^{\circ} \mathrm{C} / \mathrm{W}$ under $4.2 \mathrm{~W}$ power and the thermal resistance (RT) of CNT film can be measured to be $12.5^{\circ} \mathrm{C} / \mathrm{W}$ under $4.2 \mathrm{~W}$ power which is the lower than D-1 and D-2 structures. Table $\mathrm{V}$ demonstrates the experimental results for junction temperature and thermal resistance measurements on model D structure.

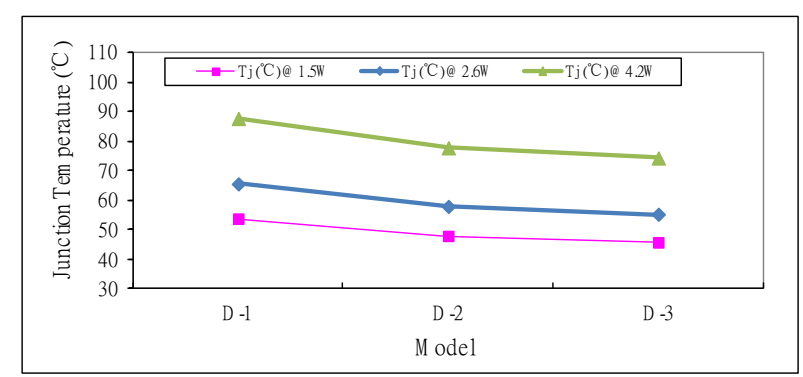

Fig. 8. Junction temperature measurement under $1.5 \mathrm{~W}, 2.6 \mathrm{~W}$ and $4.2 \mathrm{~W}$ conditions on model D structure.

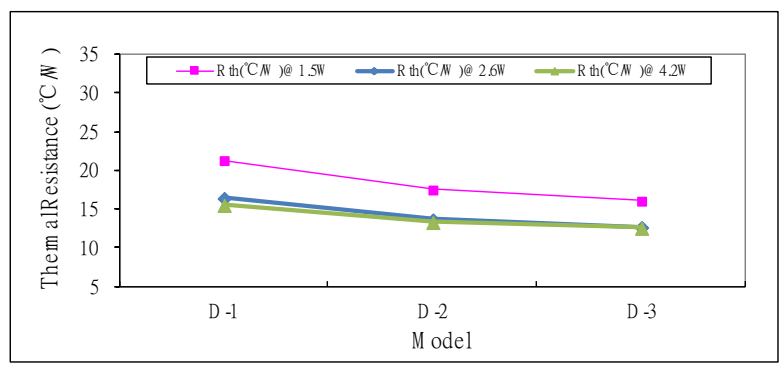

Fig. 9. Thermal resistance measurement under $1.5 \mathrm{~W}, 2.6 \mathrm{~W}$ and $4.2 \mathrm{~W}$ conditions on model D structure.

From the experiments result, for model E structure, Fig. 10 
shows the junction temperature of diamond film can be decreased by about $10.9 \%$ under $4.2 \mathrm{~W}$ power and the junction temperature of CNT film can be decreased by about $13.2 \%$ under $4.2 \mathrm{~W}$ power for $1 \mathrm{~mm}$ square die. Fig. 11 shows the thermal resistance of junction to air on model B structure, the thermal resistance (RT) of diamond film can be measured to be $12.7^{\circ} \mathrm{C} / \mathrm{W}$ under $4.2 \mathrm{~W}$ power and the thermal resistance (RT) of CNT film can be measured to be $12.4^{\circ} \mathrm{C} / \mathrm{W}$ under $4.2 \mathrm{~W}$ power which is the lower than E- 1 and $\mathrm{E}-2$ structures. Table VI demonstrates the experimental results for junction temperature and thermal resistance measurements on model E structure.

TABLE V: EXPERIMENTAL RESULTS OF JUNCTION TEMPERATURE AND THERMAL RESISTANCE ON MODEL D STRUCTURE

\begin{tabular}{|l|l|c|c|c|c|c|c|}
\hline Model & Structure & $\begin{array}{c}\text { Rth } \\
\left({ }^{\circ} \mathrm{C} / \mathrm{W}\right) \\
@ 1.5 \mathrm{~W}\end{array}$ & $\begin{array}{c}\mathrm{Tj} \\
\left({ }^{\circ} \mathrm{C}\right) \\
@ 1.5 \mathrm{~W}\end{array}$ & $\begin{array}{c}\text { Rth } \\
\left({ }^{\circ} \mathrm{C} / \mathrm{W}\right)\end{array}$ & $\begin{array}{c}\mathrm{Tj} \\
\left({ }^{\circ} \mathrm{C}\right) \\
@ 2.6 \mathrm{~W}\end{array}$ & $\begin{array}{c}\text { Rth } \\
\left({ }^{\circ} \mathrm{C} / \mathrm{W}\right)\end{array}$ & $\begin{array}{c}\mathrm{T}) \\
\left({ }^{\circ} \mathrm{C}\right) \\
@\end{array}$ \\
\hline $\mathrm{D}-1$ & LED Structure (no heat sink) & 21.33 & 53.70 & 16.44 & 65.43 & 15.55 & 87.61 \\
\hline $\mathrm{D}-2$ & LED on Diamond Film & 17.53 & 47.80 & 13.66 & 57.79 & 13.34 & 77.68 \\
\hline D-3 & LED on CNT Film & 16.09 & 45.60 & 12.69 & 55.14 & 12.59 & 74.23 \\
\hline
\end{tabular}

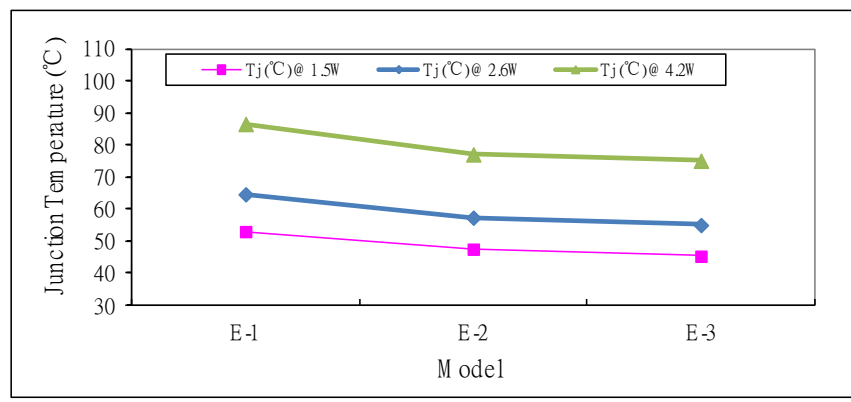

Fig. 10. Junction temperature measurement under $1.5 \mathrm{~W}, 2.6 \mathrm{~W}$ and $4.2 \mathrm{~W}$ conditions on model $\mathrm{E}$ structure.

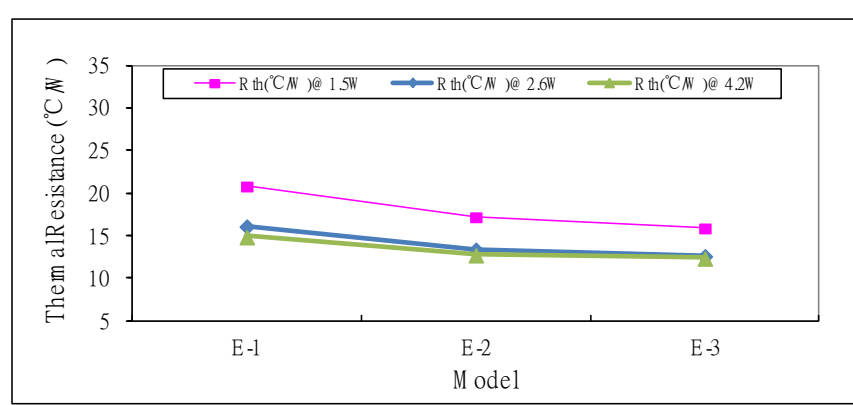

Fig. 11. Thermal resistance measurement under $1.5 \mathrm{~W}, 2.6 \mathrm{~W}$ and $4.2 \mathrm{~W}$ conditions on model E structure.

TABLE VI: EXPERIMENTAL RESULTS OF JUNCTION TEMPERATURE AND THERMAL RESISTANCE ON MODEL E STRUCTURE

\begin{tabular}{|l|l|c|c|c|c|c|c|}
\hline Model & Structure & $\begin{array}{c}\text { Rth } \\
\left({ }^{\circ} \mathrm{C} / \mathrm{W}\right) \\
@ 1.5 \mathrm{~W}\end{array}$ & $\begin{array}{c}\mathrm{Tj} \\
\left({ }^{\circ} \mathrm{C}\right)\end{array}$ & $\begin{array}{c}\text { Rth } \\
\left({ }^{\circ} \mathrm{C} / \mathrm{W}\right)\end{array}$ & $\begin{array}{c}\mathrm{Tj} \\
\left({ }^{\circ} \mathrm{C}\right)\end{array}$ & $\begin{array}{c}\mathrm{R} \text { th } \\
\left({ }^{\circ} \mathrm{C} / \mathrm{W}\right)\end{array}$ & $\begin{array}{c}\mathrm{Tj} \\
\left({ }^{\circ} \mathrm{C}\right)\end{array}$ \\
\hline E-1 & LED Structure (no heat sink) & 20.87 & 53.10 & 16.16 & 64.74 & 14.92 & 86.71 \\
\hline E-2 & LED on Diamond Film & 17.26 & 47.60 & 13.43 & 57.44 & 12.79 & 77.22 \\
\hline E-3 & LED on CNT Film & 15.94 & 45.40 & 12.67 & 55.14 & 12.40 & 75.23 \\
\hline
\end{tabular}

From the experiments result, for model F structure, Fig. 12 shows the junction temperature of diamond film can be decreased by about $11.6 \%$ under $4.2 \mathrm{~W}$ power and the junction temperature of CNT film can be decreased by about $14.2 \%$ under $4.2 \mathrm{~W}$ power for $1 \mathrm{~mm}$ square die. Fig. 13 shows the thermal resistance of junction to air on model B structure, the thermal resistance (RT) of diamond film can be measured to be $12.6^{\circ} \mathrm{C} / \mathrm{W}$ under $4.2 \mathrm{~W}$ power and the thermal resistance (RT) of CNT film can be measured to be $12.2^{\circ} \mathrm{C} / \mathrm{W}$ under $4.2 \mathrm{~W}$ power which is the lower than F-1 and F-2 structures. Table VII demonstrates the experimental results for junction temperature and thermal resistance measurements on model F structure.

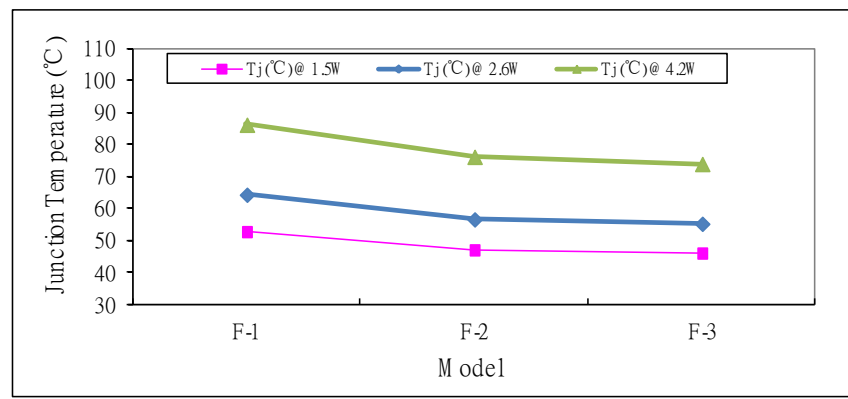

Fig. 12. Junction temperature measurement under 1.5W, 2.6W and 4.2W conditions on model F structure.

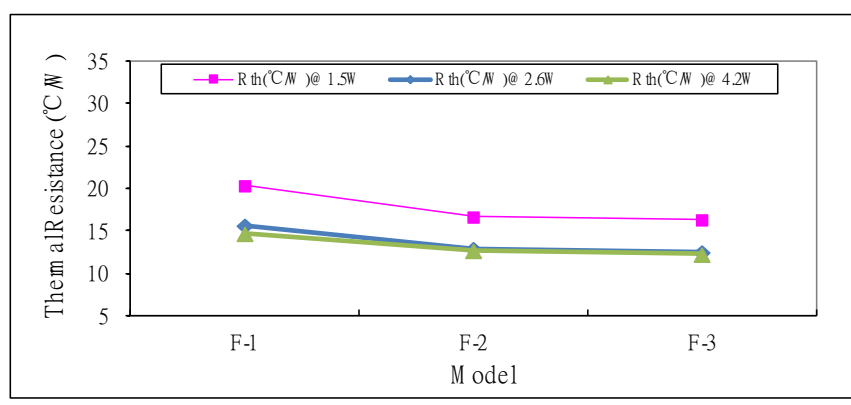

Fig. 13. Thermal resistance measurement under $1.5 \mathrm{~W}, 2.6 \mathrm{~W}$ and $4.2 \mathrm{~W}$ conditions on model F structure.

TABLE VII: EXPERIMENTAL RESULTS OF JUNCTION TEMPERATURE AND THERMAL RESISTANCE ON MODEL F STRUCTURE

\begin{tabular}{|l|l|c|c|c|c|c|c|}
\hline Model & Structure & $\begin{array}{c}\text { Rth } \\
\left({ }^{\circ} \mathrm{C} / \mathrm{W}\right) \\
@ 1.5 \mathrm{~W}\end{array}$ & $\begin{array}{c}\mathrm{Tj} \\
\left({ }^{\circ} \mathrm{C}\right)\end{array}$ & $\begin{array}{c}\text { Rth } \\
\left({ }^{\circ} \mathrm{C} / \mathrm{W}\right)\end{array}$ & $\begin{array}{c}\mathrm{Tj} \\
\left({ }^{\circ} \mathrm{C}\right)\end{array}$ & $\begin{array}{c}\text { Rth } \\
\left({ }^{\circ} \mathrm{C} / \mathrm{W}\right)\end{array}$ & $\begin{array}{c}\mathrm{T} \\
\left({ }^{\circ} \mathrm{C}\right)\end{array}$ \\
\hline F-1 & LED Structure (no heat sink) & 20.36 & 52.90 & 15.64 & 64.42 & 14.69 & 86.30 \\
\hline F-2 & LED on Diamond Film & 16.67 & 47.20 & 12.89 & 56.71 & 12.68 & 76.27 \\
\hline F-3 & LED on CNT Film & 16.34 & 46.20 & 12.49 & 55.34 & 12.23 & 74.03 \\
\hline
\end{tabular}

From above experiments result, for model F-3 structure, the junction temperature and the thermal resistance (RT) of CNT film under $4.2 \mathrm{~W}$ power which is the lowest. Because the CNT film has higher thermal conductivity than others. In physics, thermal conductivity is the property of a material to conduct heat. Secondary, for model F-2 structure, the junction temperature and the thermal resistance (RT) of diamond film under $4.2 \mathrm{~W}$ power which is the second lower than other structures. Therefore, the $\mathrm{F}$ structure has best lower than other structure base in the big size area of $\mathrm{Cu}$ plat which can dissipate heat and transfer it outside.

For model E-3 structure, the junction temperature and the thermal resistance (RT) of CNT film under $4.2 \mathrm{~W}$ power which is lower than that of other E-2 and E-1 structures. Secondary, for model E-2 structure, the junction temperature and the thermal resistance (RT) of diamond film under $4.2 \mathrm{~W}$ power which is the second lower than E-1 structures. Therefore, the E structure is second lower than other structure base in the area of $\mathrm{Cu} / \mathrm{AL}$ plat which can dissipate heat and transfer it outside. Finally, the thermal conductivity and material area will impact the thermal resistance and junction temperature.

\section{SUMMARY}

1) LED GaN Epitaxy with sapphire mounted on CNT film was found the most effective package method in heat 
dissipation.

2) The junction temperature of diamond films on model $F$ structure can be decreased by $11.6 \%$ under $4.2 \mathrm{~W}$ condition. The junction temperature of CNT film on model $\mathrm{F}$ structure can be decreased by $14.2 \%$ under $4.2 \mathrm{~W}$ condition, respectively comparable to that on no heat sink structure.

3) The thermal resistance of junction to air on model $F$ structure is measured to be $12.6^{\circ} \mathrm{C} / \mathrm{W}$ at $4.2 \mathrm{~W}$ condition of diamond film. The thermal resistance of junction to air on model $\mathrm{F}$ structure is measured to be $12.2^{\circ} \mathrm{C} / \mathrm{W}$ at $4.2 \mathrm{~W}$ condition of CNT film, respectively which is the lowest than that of other structures.

\section{REFERENCES}

[1] N. C. Chen, C. M. Lin, Y. K. Yang, C. Shen, T. W. Wang, and M. C. Wu, Jpn. J. Appl. Phys., vol. 47, no. 12, 2008.

[2] Q. Cheng, IEEE, 1-4244-1392-3/07, 2007.

[3] J. Bielecki, A. S. Jwania, F. E. Khatib, and T. Poorman, IEEE, 2007, 1-4244-0959-4/07.

[4] R. Huber, "Thermal management of SMT LED," Osram Opto-semiconductors.

[5] S. J. Hon, C. T. Kuo, T. P. Chen, and M. H. Hsieh, in Proc. SPIE, vol. 6894, 2008.

[6] J. P. You, Y. He, and F. G. Shi, IMPACT, Taipei, Taiwan, 2007.

[7] M. W. Shin and S. H. Jang, "Thermal analysis of high power LED packages under the alternating current operation," Solid-State Electronics, vol. 68, pp. 48-50, 2012.

[8] H. Y, Mater, H. Tang, S. Leung, and C. Qian, "Junction temperature measurement to optimize thermal design of LED arrays," IEEE, pp. 47-51, 2015

[9] E. D. Jung and Y. L. Lee, "Development of a heat dissipating LED headlamp with silicone lens to replace halogen bulbs in used cars," Applied Thermal Engineering, vol. 86, pp. 143-150, 2015.

[10] S. P. Ying, H. K. Fu, and R. C. Hong, "The study of thermal resistance measurement of multichip LED," IEEE Transactions on
Electron Devices, vol. 62, pp. 3291-3295, 2015.

[11] S. P. Maseng and S. C. Ko, "Thermal characteristics for chip on metal package of LED lighting module," Materials Science in Semiconductor Processing, vol. 38, pp. 357-361, 2015.

[12] X. J. Zhao, Y. X. Cai, J. Wang, X. H. Li, and C. Zhang, "Thermal model design and analysis of the high-power LED automotive headlight cooling device," Applied Thermal Engineering, vol. 75, pp. 248-258, 2015.

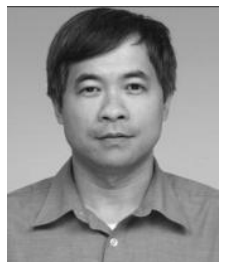

Yuli Lin was born in Taiwan in 1962. He received the M.S. from Northwestern University in 1989 in the field of mechanical engineering, and the Ph.D. degree from Northwestern University in 1992 in the field of materials science and engineering. He is a professor of mechanical engineering at Chung Hua University, Hsinchu, Taiwan, where he served as the head of the Department of Mechanical Engineering from 2003 to 2008, the dean of the College of Engineering from 2008 to 20016 and is currently the dean of the Academic Affairs.

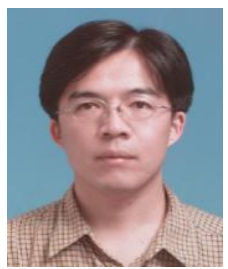

Cheng Yi Hsu was born in Taiwan in 1976. He received the M.S. from Chung Hua University in 2008 in the field of mechanical engineering. He is currently a $\mathrm{Ph} . \mathrm{D}$. student in College of Engineering, Chung Hua University. Mr. Hsu works for Tyntek corportion and serves a supervisor in Tyntek corportion, $\mathrm{R} \& \mathrm{D}$ Engineering 3st Department. 